\title{
Removal of Anionic Dye by Natural Algerian Montmorillonite
}

\section{Djelloul Bendaho*, Tabet Ainad D and Djillali B}

Laboratory of Organic Chemical-physical and Macromolecular Faculty of Exact Sciences, University Djilali Liabès, Faubourg Larbi Ben m'hjdi P.O.Box. 89, Sidi Bel-Abbès 22000, Algeria

\begin{abstract}
Adsorption of methyl orange (MO) using an Algerian montmorillonite has been investigated. Which was used for the first time like an adsorbent for removing anionic dye from aqueous solution, the influences of several parameters such as contact time, adsorbent dose, $\mathrm{pH}$ and temperature on the adsorption of methyl orange have been tested. The results showed that nearly $40 \mathrm{~min}$ of contact time are found to be sufficient for the adsorption to reach equilibrium. The residual concentration of the dye is determined using UV/Vis Spectrophotometer at wavelength $464 \mathrm{~nm}$. Langmuir and Freundlich isotherm models were used to describe adsorption data. Adsorption kinetics was best described by the pseudo-second order model.
\end{abstract}

Keywords: Dye; Adsorption; Clay; Adsorption kinetics; Adsorption isotherms

\section{Introduction}

The use of synthetic chemical dyes in various industrial processes, such as food, paper, plastic, textile, etc. are one of the most problematic water pollution causes [1]. Discharge of wastewater into natural streams and rivers from the industries using dyes poses severe environmental problems because they are usually very recalcitrant to microbial degradation. Dyes in surface waters are of barrier effect on the sun light penetration and aeration of water body, and thus reduce photosynthetic activity [2]. For these reasons, several methods are used for eliminating the excess of colored organic pollutants from process or wastes effluents including biological treatments, however, unsatisfactory results were achieved by these techniques, such as coagulation-flocculation based on the addition of coagulant and flocculants (aluminium salts and polymers) [3], but coagulation generates chemical sludge and doesn't remove acid and reactive dyes of low molecular weight Biological treatment may involve aerobic and anaerobic degradation by microorganisms [4], Adsorption using activated carbon or ion exchange resins is the most popular technique for dyes removal due to its efficiency but the activated carbon cannot adsorb dispersed and pigmented, dyes nevertheless these methods are not satisfying because of the weak colorant biodegradability $[5,6]$. Other new processes electro coagulation, advanced oxidation processes, and adsorption were elaborated to meet the required standards. Among these techniques, adsorption is considered as the most efficient technology for the removal of dyes using local materials.

In this way the majority of the processes are very selective according to the colorant categories to treat and some just move the pollution instead of removing it. It is necessary for the process to mineralize the colorant. Recent investigations by several researchers proved onto use of low-cost, reusable, locally available, biodegradable adsorbent made from natural sources like waste orange peel, banana with cotton waste, rice husk, agriculture waste residues and bentonites clay [7]. The different applications of the clay depend on their specific adsorption properties, the ion exchange and the surface nature [8]. Due to these qualities, clay is used in different field, like in medical and pharmaceutical industries, organic molecule polymerization $[9,10]$, and pollutant retention such as pesticides, organic, inorganic compounds, heavy metals [11].

The originality of this present work is to compare the performance and capacity of adsorption of methyl orange from different clays. Indeed, we propose to evaluate the removal efficiency of methyl orange in aqueous solution by adsorption using raw Algerian MMT clay. The essential parameters of the adsorption process, mainly contact time, mass of clay, temperature, initial concentration of dye, and $\mathrm{pH}$ of the aqueous solution were determined and optimized. The equilibrium of adsorption was modelled by using the Langmuir and Freundlich isotherm models, the kinetic parameters and intra-particle diffusion were also then determined for the methyl orange - Algerian MMTsystem.

\section{Materials}

\section{Preparation of MMT clay}

The clay used in this work is montmorillonite (MMT) type from Tiout region, this last was suspended in distilled water and maintained under constant stirring for 2 hours to release impurities. The suspension was then filtered and dried at $105^{\circ} \mathrm{C}$ to constant dry weight, then stored in a securely closed flask against the moisture.

\section{Dyes}

In order to show the Algerian MMT clay capacity of decoloration, we chose an organic colorant that it has methyl orange is an intensely colored compound used in dyeing and printing textiles. It is also known as C.I. Acid Orange, dye was purchased from Sigma Aldrich, heterocyclic aromatic chemical compound, having the chimical formula $\mathrm{C}_{14} \mathrm{H}_{14} \mathrm{~N}_{3} \mathrm{NaO}_{3} \mathrm{~S}$ and molecular weight of $327.33 \mathrm{~g} / \mathrm{mol}$. The structure of direct dye was given in Figure 1.

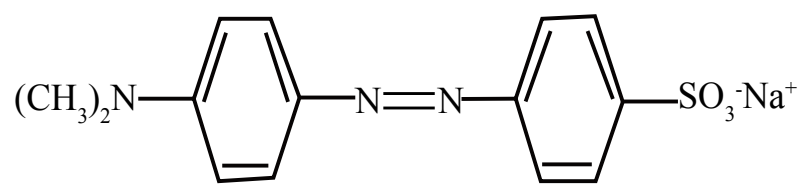

Figure 1: Chemical structure of methyl orange dye.

*Corresponding author: Djelloul Bendaho, Laboratory of organic chemicalphysical and macromolecular Faculty of exact sciences, University Djilali Liabès Faubourg Larbi Ben m'hjdi P.O.Box. 89, Sidi Bel-Abbès 22000, Algeria, Tel: 213077-174-9785; E-mail: bendaho_djelloul@yahoo.fr

Received December 16, 2014; Accepted February 12, 2015; Published February 25,2015

Citation: Bendaho D, Tabet Ainad D, Djillali B (2015) Removal of Anionic Dye by Natural Algerian Montmorillonite. J Environ Anal Chem 2: 130. doi:10.417223802391.1000130

Copyright: (c 2015 Bendaho D, et al. This is an open-access article distributed under the terms of the Creative Commons Attribution License, which permits unrestricted use, distribution, and reproduction in any medium, provided the original author and source are credited. 
Citation: Bendaho D, Tabet Ainad D, Djillali B (2015) Removal of Anionic Dye by Natural Algerian Montmorillonite. J Environ Anal Chem 2: 130. doi:10.41722380-2391.1000130

Page 2 of 6

\section{Characterization of MMT clay}

Chemical analysis showed the clay used is composed essentially of silica and alumina approximately $71.5 \%$ and of iron oxide $7.30 \%$, Chemical compositions in mass \% of raw clay obtained are listed in Table 1 , the presence of ions $\mathrm{Na}^{+}, \mathrm{Ca}^{+}$and $\mathrm{K}^{+}$in the clay gives it a swelling type. The ratio $\mathrm{SiO}_{2} / \mathrm{Al}_{2} \mathrm{O}_{3}=3.51$ reveals its montmorillonite characteristics it have both Bronsted and Lewis acid sites and when exchanged with cations having a high charge density, in the other hand (Table 1) samaruzed diference between Algerian MMT and other MMT such as American and French. Raw clay from Algerian has 5.68\% more $\mathrm{SiO}_{2}$ than (Vienne, France) and $1.68 \%$ less $\mathrm{SiO}_{2}$ than (Wyoming, USA), in the other hand the Algerian MMT contains 5.42\% and 5.32\% less $\mathrm{A}_{2} \mathrm{O}_{3}$ than the Wyoming and Vienne bentonites, respectively.

Qualitative analysis of Algerian MMT is performed by FTIR transmission spectra using $\mathrm{KBr}$ technique. The analysis was carried out

\begin{tabular}{|c|c|c|c|}
\hline Elements & Wyoming USA & Vienne French & Tiout Algeria \\
\hline $\mathrm{SiO}_{2}$ & 57.40 & 50.04 & 55.72 \\
\hline $\mathrm{Al}_{2} \mathrm{O}_{3}$ & 20.27 & 20.17 & 15.85 \\
\hline $\mathrm{Fe}_{2} \mathrm{O}_{3}$ & 2.92 & 0.68 & 7.30 \\
\hline $\mathrm{FeO}$ & 0.19 & 9 & - \\
\hline $\mathrm{CaO}$ & 0.23 & 1.46 & 4.11 \\
\hline $\mathrm{MgO}$ & 3.13 & 0.23 & 2.26 \\
\hline $\mathrm{K}_{2} \mathrm{O}$ & 0.28 & 1.27 & 4.08 \\
\hline $\mathrm{Na}_{2} \mathrm{O}$ & 1.32 & traces & 1.30 \\
\hline $\mathrm{TiO}_{2}$ & 0.12 & 0.16 & - \\
\hline $\mathrm{SO}_{3}$ & - & - & 0.43 \\
\hline $\mathrm{SO}_{3 g y p}$ & - & - & 1.11 \\
\hline $\mathrm{H}_{2} \mathrm{O}$ & 6.85 & 26 & - \\
\hline $\mathrm{Cl}^{-}$ & - & - & 0.01 \\
\hline $\mathrm{PF}^{-}$ & - & - & 7.66 \\
\hline
\end{tabular}

Table 1: Comparison of the Composition (in \%) of American, French, and Algerian MMT.

\begin{tabular}{|l|c|}
\hline \multicolumn{1}{|c|}{ Assignment } & Raw TN clay $\mathbf{~ c m}^{-1}$ \\
\hline $\mathrm{Al}-\mathrm{OH}$ & 3620 \\
$\mathrm{H}-\mathrm{OH}$ stretching (for $\mathrm{H}_{2} \mathrm{O}$ ) & 3435 \\
$\mathrm{Si}-\mathrm{O}-\mathrm{Si}$ stretching & 1031 \\
$\mathrm{H}-\mathrm{OH}$ bending & 1638 \\
$\mathrm{Si}-\mathrm{O}$ stretching ( for silice) & 797 \\
$\mathrm{Si}-\mathrm{O}-\mathrm{Al}$ & 531 \\
$\mathrm{Si}-\mathrm{O}-\mathrm{Mg}$ & 467 \\
$\mathrm{Fe}_{2} \mathrm{O}_{3}$ & 2071 \\
\hline
\end{tabular}

Table 2: FTIR spectra data of raw Algerian clay.

on Perkin Elmer precisely Spectrum One FT-IR Spectrometer in the wave number range of $400-4000 \mathrm{~cm}^{-1}$. The FTIR spectrum of TN clay was showed in Figure 2 and the FT-IR results are represented in Table 2.

The mineralogical composition of the montmorillonite was performed on by X-ray diffraction (XRD) using DRX.D8 ADVANCE (BRUKER) X-Ray powder diffractrometer operanting with Ka radiation of $\mathrm{Cu}(\lambda=1,5406 \AA)$, and $2 \theta$ ranging from $2^{\circ}$ to $80^{\circ}$. The Xray spectrum shows that the Algerian raw clay is a mixture of monmorillonite and impuretes of calcite and quartz (Figure 3).

\section{Adsorption experiments}

Adsorption experiments were carried out at room temperature (22 $\pm 2^{\circ} \mathrm{C}$ ). Approximately $80 \mathrm{mg}$ of Algerian montmorillonite (MMT) was weighted into $100 \mathrm{ml}$ glass containers and brought into contact with 50 $\mathrm{ml}$ of dye solution with predetermined initial dye concentrations $\mathrm{C}_{0}$. The obtained suspensions were maintained under constant magnetic stirring during the necessary time to reach adsorption equilibrium. The adsorption tests are perfumed at natural $\mathrm{pH}$, room temperature and stirring at different time intervals. After equilibrium, the aqueous phase was separated by centrifugation. The concentration of the residual dye was determined using a UV-Vis spectrophotometer (SHIMADZU $1240)$ at $664 \mathrm{~nm}$. The adsorption equilibrium capacity $\left(\mathrm{q}_{\mathrm{e}}\right)(\mathrm{mg} / \mathrm{g})$ was calculated from the following equation:

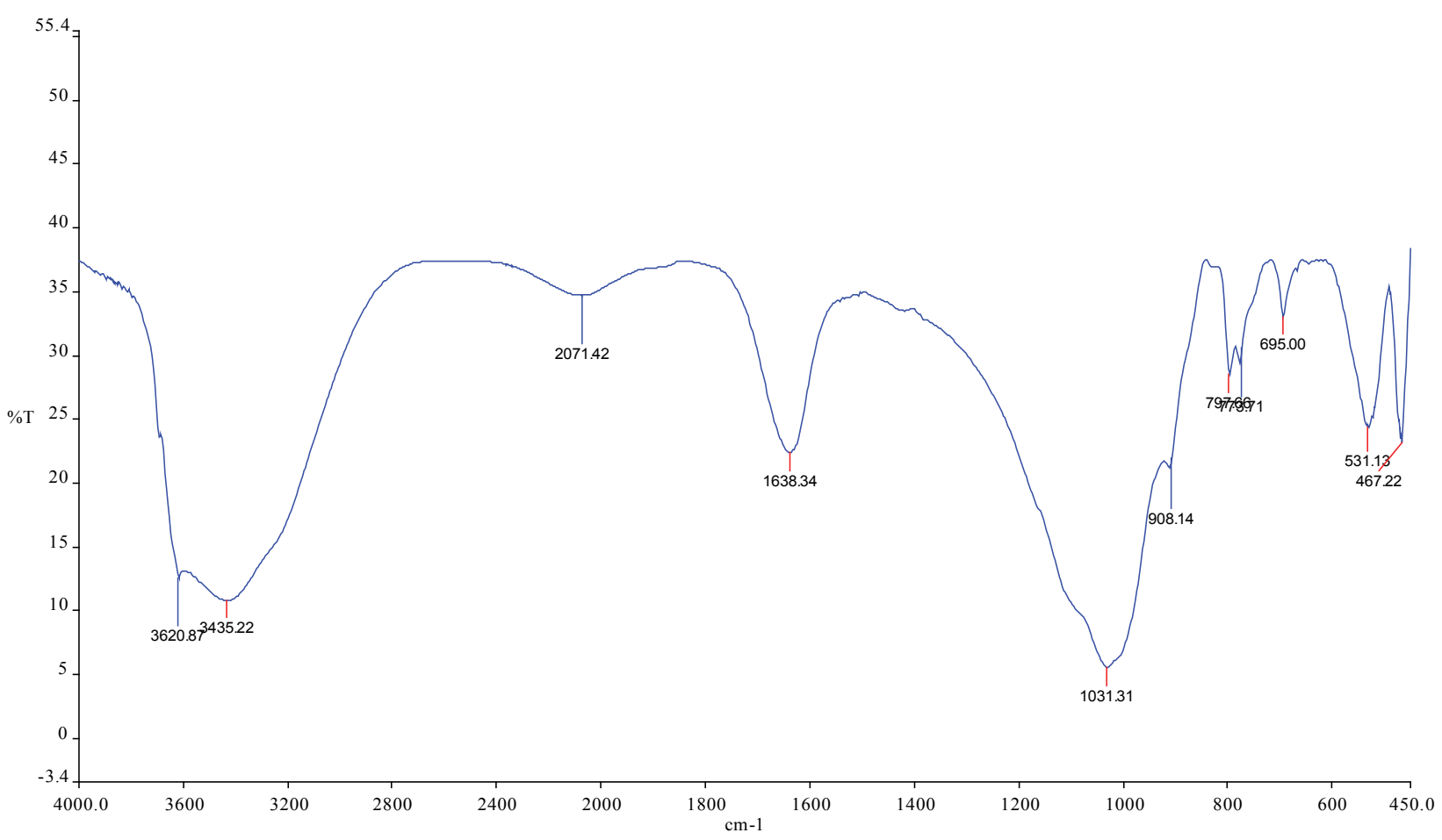

Figure 2: FTIR spectra of raw Algerian clay. 


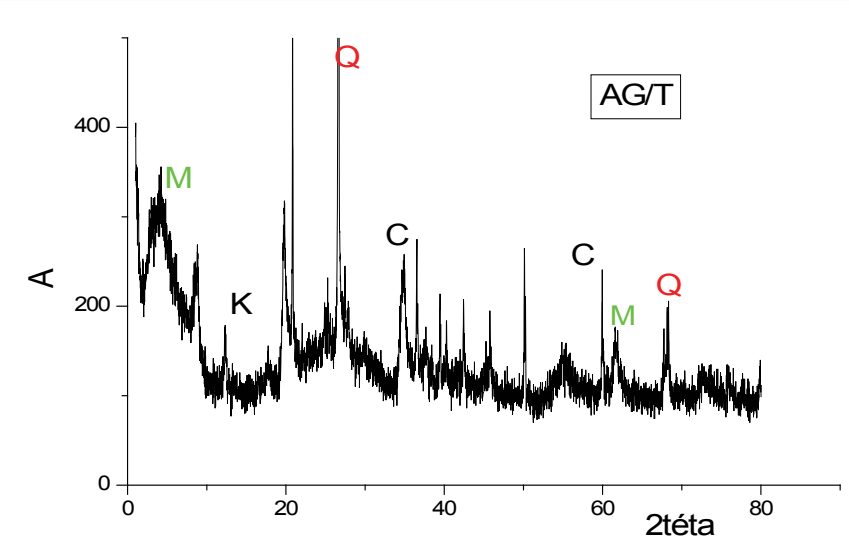

Figure 3: XDR result for raw Algerian clay.

$$
q_{e}=\left(c_{0}-c_{e}\right) \cdot v / m
$$

$\mathrm{q}_{\mathrm{e}}$ : is the amount of dye adsorbed at equilibrium $(\mathrm{mg} / \mathrm{g})$.

$\mathrm{C}_{0}$ and $\mathrm{C}_{\mathrm{e}}$ are the initial and equilibrium concentrations of the dye, respectively $(\mathrm{mg} / \mathrm{l})$.

$\mathrm{V}$ : is the volume of the solution (l).

$\mathrm{m}$ : is the mass of the adsorbent $(\mathrm{g})$.

\section{Results and Discussion}

\section{Effect of contact time}

The influence of time is achieved at natural $\mathrm{pH}$ of the solution for an initial dye concentration $26.186 \mathrm{mg} / \mathrm{l}$, with $80 \mathrm{mg} / 1$ of raw clay and room temperature. The amount of colorant adsorbed $\mathrm{q}_{t}$ at time $\mathrm{t}$ was determined by the following expression:

$$
q_{t}=\left(c_{0}-c_{t}\right) \cdot v / m
$$

Where;

$\mathrm{q}_{\mathrm{t}}$ is the amount of dye adsorbed at time $\mathrm{t}(\mathrm{mg} / \mathrm{l})$

$\mathrm{C}_{0}$ and $\mathrm{C}_{\mathrm{t}}$ are the concentrations of the dye at initial $(\mathrm{t}=0)$ and at time $t$, respectively.

Figure 4 shows the time course of adsorption equilibrium of methyl orange onto raw clay. The amount of dye adsorbed by adsorption on raw clay was found to be rapid at the initial period between (0-40 min) of contact time and then become slow and stagnant with increase in contact time (40-180 $\mathrm{min})$. This was due to the fact that, at the initial stage the number of free adsorption sites was higher, and the slow adsorption rate in the later stage was due to slower diffusion of solute into the interior of the adsorbent $[12,13]$. The maximum adsorption occurred after $60 \mathrm{~min}$ and there was almost no adsorption beyond this time.

\section{Kinetics order}

The kinetic studies describe the rate of adsorption and this rate controls the equilibrium time. These kinetic models are useful for the design and optimization of effluent treatment models. Pseudo first order, pseudo second order,

The second order kinetic model has the following formula.

$$
d q / d t=k \cdot\left(q_{e}-q_{t}\right)^{2}
$$

Where $k$ is the rate constant of second-order adsorption has the following formula.

$$
1 /\left(q_{e}-q_{t}\right)=1 / q_{e}+k \cdot t
$$

For the pseudo-second-order model is given by the following equation.

$$
d q_{t} / d q_{e}=k^{\prime} \cdot\left(q_{e}-q_{t}\right)^{2}
$$

Where $k^{\prime}$ is the rate constant of pseudo-second-order adsorption has the following formula.

$$
t / q_{t}=1 /\left(k^{\prime} \cdot q_{e}^{2}\right)+t / q_{e}
$$

The kinetic data obtained using the second order and pseudosecond order is depicted in Figures 5 and 6 . The $\mathrm{q}_{e}$ value calculated from the pseudo-second-order model is in accordance with the experimental

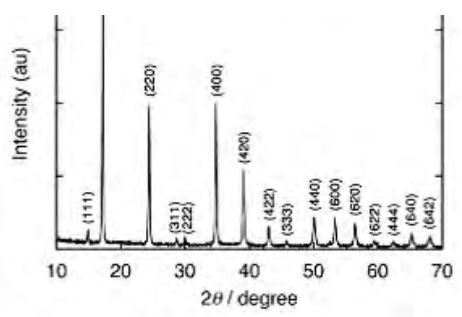

(a)

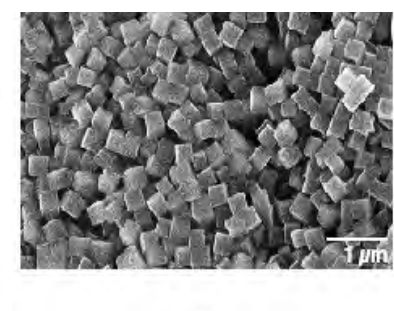

(b)
Figure 4: The effect of contact time on the adsorption of MO on Algerian MMT.



Figure 5: Plot of $t / \mathrm{q}_{\mathrm{e}}$ versus $\mathrm{t}$ from the pseudo-second-order model.

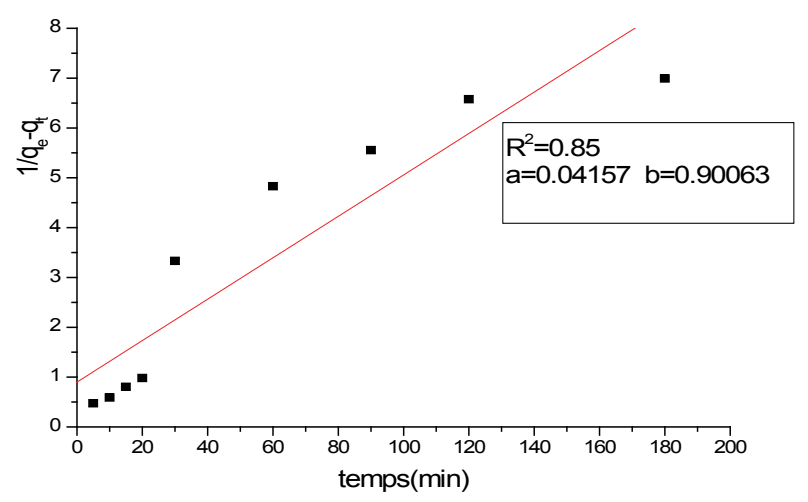

Figure 6: Plot $1 / q_{e}-q_{t}$ versus $t$ from the second-order model. 
$\mathrm{q}_{e}$ value. The correlation coefficient $\mathrm{R}^{2}$ of the linear plot is very high. The result is shown in Table 3. The value of kinetic constant and $\mathrm{q}_{e}$ indicates that the adsorption follow the pseudo-second order model. Several studies found that the kinetics of adsorption of dyes on clay supports obey to the pseudo-second-order [14-17].

\section{Effect of adsorbent mass}

The effect of adsorbent dosage on the adsorption process can be carried out by preparing adsorbent-adsorbate solution with different amount of adsorbents (1-4 g/l) added to fix initial dye concentration $(26.186 \mathrm{mg} / \mathrm{l})$, room temperature, $\mathrm{pH}$ natural and shaken together until equilibrium time. The effect of sorbent quantity on dye removal is illustrated in Figure 7. From the figure it can be seen that an increase mass of crude clay $1 \mathrm{~g} / \mathrm{l}$ down to a value of $4 \mathrm{~g} / \mathrm{l}$ causes a decreases in residual dye concentration. The increase in methyl orange adsorption with the increase in adsorbent mass is attributed to increase in surface area of micro pores and the increase in availability of vacant adsorption sites. Similar results have been reported for the adsorption of methyl orange on Algerian MMT [18-20]

\section{Effect of $\mathbf{p H}$}

The $\mathrm{pH}$ is one of the most important factors controlling the adsorption of dye onto adsorbent. The influence of $\mathrm{pH}$ on dye removal was determined by performing the adsorption experiments at different initial $\mathrm{pH}$ of the solution $(2-11)$ at room temperature. The $\mathrm{pH}$ had been adjusted to the desired value with $\mathrm{HCl}(0.1 \mathrm{~N})$ and $\mathrm{NaOH}(0.1 \mathrm{~N})$ solutions by using a HANNA $210 \mathrm{pH}$-meter equipped with a combined $\mathrm{pH}$ electrode. The adsorption of methyl orange onto clay is highly dependent on $\mathrm{pH}$ of the solution.

Figures 8 and 9 shows the influence of the $\mathrm{pH}$ of the initial dye solution on the adsorption capacity of MO on Algerian MMT. As the $\mathrm{pH}$ value increased from 2.0 to 6.0 , the adsorption capacity of dye onto Algerian MMT rapidly decreased. The removal dye is higher in the acid $\mathrm{pH}$ region because the MO acid dye give negatively charged ions when dissolved in water, the adsorption of $\mathrm{MO}$ dye is facilitated on positively charged surface of sorbent at $\mathrm{pH}<\mathrm{pHpzc}$.

\begin{tabular}{|c|c|}
\hline Parameters & Pseudo-second-order \\
\hline $\mathrm{K}^{\prime}(\mathrm{g} / \mathrm{mg} \mathrm{min})$ & 5.218 \\
$\mathrm{q}_{\text {e cal }}(\mathrm{mg} / \mathrm{g})$ & 9.107 \\
$\mathrm{q}_{\text {e épx }}(\mathrm{mg} . / \mathrm{g})$ & 9.141 \\
$\mathrm{R}^{2}$ & 0,99 \\
\hline
\end{tabular}

Table 3: The pseudo- second -order parameters of $\mathrm{MO}$ adsorption into Algerian MMT.



Figure 7: The effect of adsorbent mass on the adsorption of MO on Algerian MMT.



Figure 8: The effect of $\mathrm{pH}$ of the solution on the adsorption of $\mathrm{MO}$ on Algerian clay.

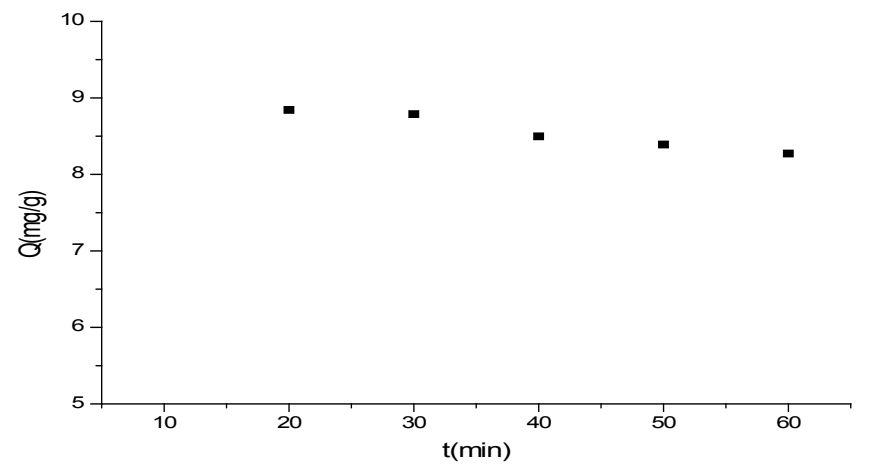

Figure 9: The effect of the temperature on the adsorption of MO on Algerian MMT.

In contrast, at a high $\mathrm{pH}$ solution the capacity of dye removal will decrease for anionic dye adsorption [21]. Because when the $\mathrm{pH}$ of dye solution is increased the surface tends to acquire negative charge, thereby resulting in a decreased adsorption of dyes due to decreasing electrostatic force existing between the negatively charged sorbate and positively charged sorbent.

\section{Effect of temperature}

The amount of dye adsorbed on Algerian MMT was determined at $20,30,40$ and $60^{\circ} \mathrm{C}$ to investigate the effect of temperature. $80 \mathrm{mg}$ of adsorbent was added to $50 \mathrm{ml}$ dye solution with initial concentration of $26.186 \mathrm{mg} / \mathrm{l}$. The contents in the flasks were agitated for $40 \mathrm{~min}$.

The decrease in the adsorption capacity of methyl orange with increasing temperature results from the weakening of adsorptive forces between the active sites on the molecule and the Algerian MMT anion of the dye, but also between the molecules dye and the adsorbed phase [22].

\section{Thermodynamic parameters}

The Gibbs energy $\Delta G$ is calculated from the given equation:

$$
\Delta G=-R T L n K c
$$

$\mathrm{Kc}$ represented the ability of the retain of the adsorbate and extent of movement of it within the solution. The value of Kc can be deduced from the following formula:

$$
K_{C}=\frac{q_{e}}{c_{e}}
$$

Where:

$\mathrm{q}_{\mathrm{e}}$ : is the amount of dye adsorbed at equilibrium $(\mathrm{mg} / \mathrm{g})$ 
$\mathrm{C}_{\mathrm{e}}$ : is the equilibrium concentration of the dye in the solution.

The thermodynamic equation:

$\Delta G=-R T L n K c$

And the Vant'Hoff formula:

$$
\Delta G=-R T L n K c
$$

Can be deduced the following formula:

$$
\ln \mathrm{Kc}=\frac{\Delta S}{R}-\frac{\Delta H}{R} \cdot \frac{1}{T}
$$

The values $\Delta S$ and $\operatorname{lnKc}$ can be obtained by plotting the $\operatorname{lnKc}$ versus $1 / \mathrm{T}$ (Figure 10).

According to the thermodynamic parameters represented in Table 4 we realized that the $\Delta \mathrm{H}$ enthalpy of the system is negative so the adsorption process on Algerian MMT is exothermic, the low value of the enthalpy $\Delta \mathrm{H}$ energy $(<20 \mathrm{Kj} / \mathrm{mole})$ shows that it is a physical adsorption, the physic sorption is generally considered to be an effective method for quickly lowering the concentration of dissolved dyes in an

\begin{tabular}{|c|c|c|c|c|c|c|}
\hline Adsorbent & Colorant & $\mathbf{T}(\mathrm{K})$ & $\Delta \mathbf{G}(\mathbf{K j} / \mathrm{mol})$ & $\Delta \mathbf{H}(\mathrm{Kj} / \mathrm{mol})$ & $\Delta \mathrm{S}(\mathrm{J} / \mathrm{mol} . \mathrm{K})$ & $\mathbf{R}^{2}$ \\
\hline \multirow{5}{*}{ Algerian MMT } & \multirow{5}{*}{ MO } & 293 & -4.251 & -2.241 & 6.862 & \multirow{5}{*}{0.96} \\
\hline & & 303 & -4.320 & - & - & \\
\hline & & 313 & -4.388 & _ & - & \\
\hline & & 323 & -4.457 & - & - & \\
\hline & & 333 & -4.526 & - & - & \\
\hline
\end{tabular}
effluent, Adsorption takes place in multilayer, The negative values of

Table 4: Thermodynamic parameters of MO adsorption into Algerian clay.

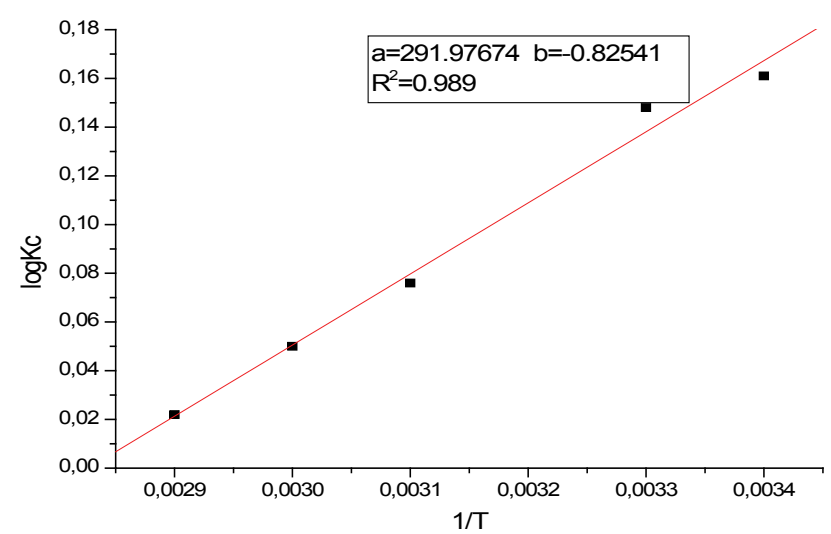

Figure 10: plot of $\ln K d$ versus $1 / T$ for the estimation of thermodynamic parameters.

\begin{tabular}{|c|c|c|c|}
\hline Langmuir & $\mathrm{Q}_{\max }=27.824$ & $\mathrm{~b}=1.2397$ & $\mathrm{R}^{2}=0.99$ \\
\cline { 1 - 1 } Freundlich & $\operatorname{LogK}_{\mathrm{F}}=0.208$ & $1 / \mathrm{n}=0.64$ & $\mathrm{R}^{2}=0.96$ \\
\hline
\end{tabular}

Table 5: Isotherm constants for adsorption of methyl orange into Algerian MMT.
$\Delta \mathrm{G}^{\circ}$ for Algerian MMT adsorbent at various temperatures indicate the process to be feasible and spontaneous. Actually that the values of the $\Delta \mathrm{G}^{\circ}$ decrease with increasing temperature shows the increase of spontaneous influence [23].

\section{Adsorption isotherms and models}

An adsorption isotherm is the presentation of the amount of solute adsorbed per unit weight of adsorbent as a function of the equilibrium concentration in the bulk solution at constant temperature. Langmuir and Freundlich adsorption isotherms are commonly used for the description of adsorption data.

The Langmuir isotherm is valid for monolayer adsorption onto a surface with a finite number of identical sites. The homogeneous Langmuir adsorption isotherm is represented by the following equation.

$$
q_{e}=q_{\max } \cdot b C_{e} /\left(1+b C_{e}\right)
$$

Where $q_{e}$ is the amount adsorbed at equilibrium $(\mathrm{mg} / \mathrm{g}), C_{e}$ the equilibrium concentration $(\mathrm{mg} / \mathrm{l}), b$ a constant related to the adsorption energy $(1 / \mathrm{mg})$, and $q_{\max }$ the maximum adsorption capacity $(\mathrm{mg} / \mathrm{g})$.

The linear form of Langmuir equation may be written as.

$$
q_{e}=C_{e}^{1 / n} \cdot K_{F}
$$

By plotting $\left(1 / q_{e}\right)$ versus $C_{e}, q_{\max }$ and $b$ can be determined if a straight line is obtained.

The Freundlich isotherm is an empirical equation assuming that the adsorption process takes place on heterogeneous surfaces, and adsorption capacity is related to the concentration of colorant at equilibrium. The heterogeneous Freundlich adsorption isotherm is represented by the following equation:

$$
q_{e}=C_{e}{ }^{1 / n} \cdot K_{F}
$$

Where the $\mathrm{K}_{\mathrm{F}}$ is Freundlich constant related to the adsorption capacity $(\mathrm{mg} / \mathrm{g})$ and $1 / \mathrm{n}$ is indicative of the energy or intensity of the reaction and suggests the favourability and capacity of the adsorbent/ adsorbate systems $(1 / \mathrm{mg})$.

The linear form of Freundlich equation may be written as

$$
\log q_{e}=\frac{1}{n} \cdot \log C_{e}+\log \mathrm{K}_{F}
$$

The values of $\mathrm{K}_{F}$ and $\frac{1}{n}$ can be determined by plotting the $\log q_{e}$ versus $\log C_{e}$, if a straight line is obtained.

The isotherm parameters for the adsorption of MO onto Algerian

\begin{tabular}{|c|c|c|c|}
\hline Adsorbent & adsorbate & $\begin{array}{l}\text { Adsorption capacity } \\
\text { (mg/g) }\end{array}$ & Reference \\
\hline Bentonite & Malachite Green & 7.716 & Tahir and Rauf [17] \\
\hline Bentonite algeria & Rouge bezanyl & 39.11 & Benguella and Yacouta-Nour [18] \\
\hline Na-Bentonite And Ca-Bentonite & Basic Violet 14 & 147.9 and 100 & Jiang et al. \\
\hline Crude And Purified Clay & Methylene Blue & 50 and $68, .5$ & Karim et al. \\
\hline chitosan intercalated montmorillonite & Methyl orange & 70.42 & Chakkrit Umpuch and \\
\hline Natural ClayCu(II)-Loaded MMT & Crystal Violet & 25 and 42 & Songsak Sakaew In this study \\
\hline Algerian clay MMT & Metlyl orange & 27.86 & \\
\hline
\end{tabular}
MMT are summarised in Table 5. It can be seen, the result revealed that the adsorption of methyl orange dye onto Algerian MMT was the bestfit both Langmuir and Freundlich isotherms.

Furthermore, values of $1 / \mathrm{n}$ were between zero and one, which indicates that Algerian MMT is favourable for the adsorption of MO

Table 6: Comparison of the adsorption capacity of dyes onto adsorbents such as clay. 
Citation: Bendaho D, Tabet Ainad D, Djillali B (2015) Removal of Anionic Dye by Natural Algerian Montmorillonite. J Environ Anal Chem 2: 130. doi:10.41722380-2391.1000130

Page 6 of 6

dye under the experimental conditions employed [24]. The comparison of adsorption capacities of various materials is given in Table 6 .

\section{Reference}

1. Annadurai G, Ling LY, Lee JF (2008) Adsorption of reactive dye from an aqueous solution by chitosan: isotherm, kinetic and thermodynamic analysis. $J$ Hazard Mater 152: 337-346.

2. Salleh MAM, Mahmoud DK, Karin WA, Idris A (2011) Cationic and anionic dye adsorption by agricultural solid wastes: A comprehensive review. Desalination 280: 1-13.

3. Shi B, Li G, Wang D, Feng C, Tang H (2007) Removal of direct dyes by coagulation: the performance of preformed polymeric aluminum species. J Hazard Mater 143: 567-574.

4. Nkurunziza T, Nduwayezu JB, Banadda EN, Nhapi I (2009) The effect of turbidity levels and Moringa oleifera concentration on the effectiveness of coagulation in water treatment. Water Sci Technol 59: 1551-1558.

5. Khenifi A, Sekrane F, Kameche M, Deriche Z (2007) Adsorption study of an industrial dye by organic clay. Adsorption 13: 149-158.

6. Chen S, Zhang J, Zhang C, Yue Q, Li Y, et al. (2010) Equilibrium and kinetic studies of methyl orange and methyl violet adsorption on activated carbon derived from Phragmites australis. Desalination 252: 149-156.

7. Robinson T, Chandran B, Nigam P (2002) Removal of dyes from an artificial textile dye effluent by two agricultural waste residues, corncob and barley husk. Environ Int 28: 29-33.

8. Grses A, DoAYar C, YalAin M, Aikyildiz M, Bayrak R, et al. (2006) The adsorption kinetics of the cationic dye, methylene blue, onto clay. J Hazard Mater 131: 217-228.

9. Medjdoub L, Rahmouni A, Belbachir M (2014) New approach for synthesis of hexa (allylamino) cyclotriphosphazene catalysed by an ecologically friendly catalyst called Maghnite- $\mathrm{H}+$ derived from Algerian MMT 2: 046-053.

10. Ferrahi MI, Belbachir M (2005) Synthesis of cyclic polyesters of poly (oxybutylene oxymaleoyl). J Polym Res 12: 167-171.

11. Ismail MA, Eltayeb MAZ, Abdel Maged SA (2013) Elimination of Heavy Metals from Aqueous Solutions using Zeolite LTA Synthesized from Sudanese Clay 3: 93-98.
12. Wibulswas $R$ (2004) Bach and fixed bed sorption of methylene blue on precursor and QUACs modified montmorillonite. Sep Purif Technol 39: 3-12.

13. Almeida CA, Debacher NA, Downs AJ, Cottet L, Mello CA (2009) Removal of methylene blue from colored effluents by adsorption on montmorillonite clay. $\mathrm{J}$ Colloid Interface Sci 332: 46-53.

14. DoÄŸan M, Alkan M, TÃrkyilmaz A, Ozdemir Y (2004) Kinetics and mechanism of removal of methylene blue by adsorption onto perlite. J Hazard Mater 109 141-148.

15. Ho YS, Chiang CC, Hsu YC (2001) Sorption kinetics for dye removal from aqueous solution using activated clay. Separation Science and Technology 36: 2473-2488.

16. Ferrero $F(2010)$ Adsorption of Methylene Blue on magnesium silicate: kinetics, equilibria and comparison with other adsorbents. J Environ Sci (China) 22: 467 473.

17. Tahir SS, Rauf $N$ (2006) Removal of a cationic dye from aqueous solutions by adsorption onto bentonite clay. Chemosphere 63: 1842-1848.

18. Benguella B, Yacouta-Nour A (2009) elimination des colorants acids en solution aqueous par la bentonite et le kaolin. CR Chimie 12: 762-771.

19. Bhakta JN, Munekage $Y(2013)$ Identification of potential soil adsorbent for the removal of hazardous metals from aqueous phase. Int J Environ Sci Techno 10: 315-324

20. Fil BA, Yilmaz MT, Bayar S, Elkoca MT (2014) Investigation of adsorption of the dyestuff astrazon red violet 3rn (basic violet 16) on montmorillonite clay. Braz J Chem Eng 33: 171-182.

21. ElOuardi M, Said A, Samir Q, Abdelhadi A, Ali A, et al. (2013) Removal of Carbaryl Pesticide from Aqueous Solution by Adsorption on Local Clay in Agadir. American Journal of Analytical Chemistry 4: 72-79.

22. Tsai WTY, Chang YM, Lai CW, Lo CC (2005) Adsorption of Basic Dyes in Aqueous Solution by Clay Ad- sorbent from Regenerated Bleaching Earth. Applied Clay Science 29: 149-154.

23. Venkat SM, Indra DM, Vimal CS (2007) Use of Bagasse Fly Ash as an Adsorbent for the Removal of Brilliant Green Dye from Aqueous Solution. Dyes Pigments 73: 269-278.

24. Zhu L (2008) efficient removal and mechanisms of water soluble aromatic contaminants by a reduced-charge bentonite modified with benzyl tri methyl ammonium cation. Chemosphere 70: 1987-1994. 